\title{
EFEKTIFITAS PROGRAM DIKLAT BERJENJANG TINGKAT DASAR BAGI GURU PAUD DALAM JARINGAN DI KOTA DEPOK
}

\author{
Erni Rosydiana, Happy Indira Dewi, Widia Winata \\ Magister Teknologi Pendidikan Fakultas Ilmu Pendidikan \\ Universitas Muhammadiyah Jakarta \\ email: ernirosydiana@yahoo.co.id
}

\begin{abstract}
This research is motivated by the qualifications of educators who have not been in line with expectations, lack of competence, lack of confidence in self-development, this is a condition that needs special attention and serious efforts. One effort was made in improving the quality of services for PAUD educators with the provision of training, namely tiered level training for PAUD teachers in the network. This study uses qualitative methods, especially naturalistic. The research analysis process follows the models of Miles and Huberman. The purpose of this study is to describe of the implementation of basic level education and training programs for PAUD teachers in the network, in addition to providing input into the basic level education and training program policies for PAUD teachers in the network. The process of collecting data using observation, interviews and documents. Data analysis includes analysis of data reduction, data display, and data verification. The results of the study show the effectiveness of the implementation of a basic level training program for PAUD teachers in a network in the city of Depok in the hope that it can be useful for relevant parties who can use such as principals, teachers, administrators, admin, mentors and further researchers.
\end{abstract}

Keywords: Effectiveness, Basic Level Training Programs, In Networks

\begin{abstract}
ABSTRAK
Penelitian ini dilatarbelakangi oleh kualifikasi pendidik yang belum sesuai dengan harapan, kurangnya kompetensi, kurang percaya diri dalam pengembangan diri. Hal ini merupakan kondisi yang perlu mendapat perhatian khusus dan upaya serius. Salah satu upaya yang dilakukan dalam meningkatkan kualitas pelayanan bagi pendidik PAUD dengan pemberian pelatihan yaitu pelatihan berjenjang bagi guru PAUD dalam jaringan. Penelitian ini menggunakan metode kualitatif, khususnya naturalistik. Proses analisis penelitian mengikuti model Miles dan Huberman. Tujuan dari penelitian ini adalah untuk mendeskripsikan pelaksanaan program pendidikan dan pelatihan tingkat dasar bagi guru PAUD dalam jaringan, selain memberikan masukan terhadap kebijakan program pendidikan dan pelatihan tingkat dasar bagi guru PAUD dalam jaringan. Proses pengumpulan data menggunakan observasi, wawancara dan dokumen. Analisis data meliputi analisis reduksi data, penyajian data, dan verifikasi data. Hasil penelitian menunjukkan efektifitas pelaksanaan program pelatihan tingkat dasar bagi guru PAUD dalam jaringan di kota Depok dengan harapan dapat bermanfaat bagi pihak-pihak terkait yang dapat memanfaatkan seperti kepala sekolah, guru, administrator, admin, pembimbing dan peneliti selanjutnya.
\end{abstract}

Kata kunci: Efektivitas, Program Pelatihan Tingkat Dasar, Dalam Jaringan

\section{PENDAHULUAN}

Pendidik PAUD adalah tenaga professional yang memiliki peran sangat penting bagi pelaksanaan suatu pembelajaran, sehingga pendidik PAUD seharusnya menjalankan tugasnya setelah kompetensi dan kualifikasi terpenuhi. 
Mengingat bahwa pendidik PAUD bertugas merencanakan, melaksanakan proses pembelajaran, menilai hasil pembelajaran serta melakukan pembimbingan, pengasuhan dan juga perlindungan terhadap peserta didik. Selain itu, perlu dikemukakan bahwa usia dini merupakan usia emas di dalam perkembangan anak. Pada usia emas tersebut anak mengalami perkembangan yang sangat pesat sehingga anak harus memperoleh rangsangan atau stimulasi yang tepat dari lingkungannya.

Berdasarkan data dapodik PAUD dan Dikmas tahun 2015 terdapat guru PAUD sejumlah 31.720 orang berpendidikan dasar (SD, SMP), 366.972 orang berpendidikan menengah (SMA/SMK sederajat), 238.186 orang berpendidikan S1 dan selebihnya sebanyak 5.678 orang berpendidikan S2. Data tersebut diatas menunjukkan bahwa guru PAUD menjalankan tugasnya melebihi kewenangan yang seharusnya dan belum sesuai dengan Permendiknas No. 16 Tahun 2007 tentang Standar kualifikasi Akademik Guru serta Permendiknas No. 137 Tahun 2014 Tentang Standar Nasional PAUD, Undang-Undang nomor 20 tahun 2003 tentang Sistem Pendidikan Nasional, Undang-Undang nomor 14 tahun 2005 tentang Guru dan Dosen.

Dalam upaya mengantisipasi permasalahan yang terjadi tersebut maka sebagai upaya dalam meningkatkan mutu dan layanan terhadap guru PAUD, Pusat Pengembangan Pendidikan Anak Usia Dini dan Pembinaan Masyarakat (PP PAUD dan Dikmas) memberikan berbagai diklat bagi guru PAUD. Di antaranya adalah Program Diklat Berjenjang (Diklat Dasar, Diklat Lanjutan dan Diklat Mahir). PP PAUD dan Dikmas membuka pendaftaran bagi calon training provider, dalam hal ini adalah organisasi mitra yaitu HIMPAUDI, IGTK dan juga BPAKSI sebagai training provider yang telah menyelenggarakan Diklat berjenjang Tingkat Dasar.
Melalui sistem ini para pendidik tidak perlu meninggalkan tugas pokok sehari-hari. Selain itu Program Diklat Berjenjang Tingkat Dasar Bagi Guru PAUD Dalam Jaringan ini dapat menjangkau wilayah yang lebih luas lagi sehingga sasarannya pun akan lebih banyak lagi. Program Diklat Berjenjang Tingkat Dasar Bagi Guru PAUD Dalam Jaringan ini memiliki karakteristik yaitu adanya keterpisahan antara pengajar dengan peserta ditinjau dari jarak, ruang dan waktu serta penggunaan media teknologi. Diklat dengan karakteristik tersebut sangatlah cocok diikuti oleh pendidik yang tidak dapat meninggalkan tempat dan tugas mengajarnya sehari-hari di samping tugas barunya sebagai peserta Program Diklat Berjenjang Tingkat Dasar Bagi Guru PAUD Dalam Jaringan.

Melihat permasalahan yang terjadi didalam proses pelaksanaan Program Diklat Berjenjang Tingkat Dasar Bagi Guru PAUD Dalam Jaringan maka peneliti merasa tertarik untuk melakukan penelitian mengenai Efektifitas Program Diklat Berjenjang Tingkat Dasar Bagi Guru PAUD Dalam Jaringan di Kota Depok tahun 2018 yang diselenggarakan oleh PP PAUD dan DIKMAS Jawa Barat.

\section{KAJIAN LITERATUR}

Program pengembangan sumber daya manusia hendaknya disusun secara cermat dan didasarkan pada metodemetode ilmiah serta berpedoman pada keterampilan yang dibutuhkan organisasi saat ini maupun masa yang akan datang. Pengembangan bertujuan untuk meningkatkan kemampuan teoritis, teknis, konseptual, dan moral pegawai agar prestasi kerjanya baik dan mencapai hasil yang optimal.

Pengembangan sumber daya manusia secara makro adalah suatu proses peningkatan kualitas dan kemampuan manusia dalam rangka mencapai suatu tujuan pembangunan bangsa. Proses peningkatan ini mencakup perencanaan 
pengembangan dan pengelolaan sumber daya manusia (Soekidjo Notoatmodjo, 2003: 4).

Pengembangan sumber daya manusia merupakan salah satu upaya untuk meningkatkan kemampuan pegawai dalam menangani berbagai jenis tugas dan menerapkan kemampuan yang dibutuhkan sesuai dengan jenis pekerjaan yang ada, sehingga pegawai dapat mengerjakan pekerjaannya secara optimal. Pengembangan kualitas dan kemampuan sumber daya manusia melalui proses perencanaan pendidikan, pelatihan, dan pengolahan tenaga atau pegawai untuk mencapai suatu hasil yang optimal.

Proses pengembangan sumber daya manusia berhubungan erat dengan konsep pendidikan dan pelatihan. Pendidikan dan pelatihan merupakan suatu cara yang pasti dilalui untuk mencapai suatu pengembangan, baik pengembangan pengetahuan, kemampuan dan ketrampilan pegawai dalam meningkatkan kinerja pegawainya.

Pendidikan menurut Fuad (2011:1) merupakan suatu usaha manusia di dalam mengembangkan serta menumbuhkan potensi yang dimiliki baik rohani maupun jasmani yang sesuai dengan kaidah-kaidah atau nilai-nilai didalam suatu kebudayaan masyarakat yang dikembangkan dalam kehidupan yang terjadi didalam suatu proses pendidikan.

Selanjutnya Sikula mengemukakan bahwa pelatihan adalah suatu proses pendidikan jangka pendek yang mempergunakan prosedur sistematis dan terorganisir di mana pegawai non managerial mempelajari pengetahuan dan ketrampilan teknis dalam tujuan terbatas (Mangkunegara, 2007: 44).

Berdasarkan uraian tersebut dapat disimpulkan bahwa pendidikan dan pelatihan merupakan proses dari serangkaian kegiatan yang mengutamakan pengetahuan, ketrampilan dan peningkatan sikap seseorang dalam melaksnakan tugas dan tanggungjawab dalam rangka pencapaian tujuan organisasi yang efektif dan efisien.

Tujuan pendidikan dan pelatihan yaitu untuk meningkatkan pengetahuan, kemampuan dan ketrampilan pegawai agar dapat bekerja lebih professional dalam menjalankan pekerjaannya sehingga tujuan organisasi dapat tercapai dan memiliki keterkaitan dengan kinerja pegawai. Adapun manfaat dari pendidikan dan pelatihan ini yaitu untuk meningkatkan stabilitas pegawai dan dapat memberikan kesempatan bagi pegawai untuk mengembangkan diri agar dalam melaksnakan tugas dapat berjalan dengan efektif dan efisien.

Penyelenggaraan program pendidikan dan pelatihan sangatlah penting bagi pegawai baik untuk masa sekarang ataupun masa yang akan datang, karena dengan adanya pendidikan dan pelatihan kemampuan pengetahuan, ketrampilan, sikap dan juga produktivitas akan semakin meningkat.

Diklat berjenjang dalam jaringan (daring) merupakan suatu jenis diklat yang dalam proses pelaksanaannya menggunakan media elektronik sebagai alat bantunya (online). Media elektronik yang digunakan bermacam-macam, salah satu di antaranya adalah dengan menggunakan media website yang diakses dengan menggunakan sarana koneksi internet. Media ini sangat penting sebagai pengganti pembelajaran di kelas sebab manajemen kelas sebagai tempat belajar merupakan faktor yang berpengaruh dalam pencapaian tujuan belajar (Iswan, dkk, 2020: 137).

Menurut Siswanto Satrohadiwiryo evaluasi diklat dilaksanakan pada waktu pra pendidikan dan pelatihan, selama pendidikan dan pelatihan, dan sesudah pendidikan dan pelatihan. Adapun penjelasannya sebagai berikut (Siswanto Satrohadiwiryo, 2003: 224-230) :

1) Evaluasi Pra Pendidikan dan Pelatihan 
2) Evaluasi Selama Diklat

3) Evaluasi Sesudah Diklat

Efektifitas organisasi dapat dipengaruhi oleh beberapa faktor, dimana falktor-faktor tersebut dapat dikelompokkan ke dalam faktor intern dan ekstern organisasi (Mohyi, 1999: 214). Berikut faktor intern yang mempengaruhi efektifitas organisasi:

1) Faktor organisasi dan teknologi yang digunakan

2) Kulaitas dan perilaku sumber daya manusia

3) Budaya yang ada dalam organisasi

4) Kebijakan dan praktek manajemen

Faktor eksternnya meliputi keadaan perekonomian, kebijakan pemerintah, politik, sosial budaya, konsumen, dan supplier dll.

Pengukuran efektifitas program pelatihan/training dapat dilakukan dengan empat langkah, yaitu:

1) Penilaian Kinerja Pra Training

2) Monitoring Pelaksanaan Program Training

3) Monitoring EfektifitasTraining

4) Pencatatan Di Lembar Penilaian

\section{METODE PENELITIAN}

Penelitian evaluasi program ini dilakukan di Kota Depok, provinsi Jawa Barat. Evaluasi program dalam penelian ini dimaksudkan sebagai serangkaian metode penelitian sosial yang meliputi proses pengumpulan informasi sebagai dasar untuk menilai sebuah program berdasarkan kriteria atau tujuan yang telah ditetapkan dengan maksud untuk membantu keputusan mengenai objek yang dievaluasi (Suradika dan Dirgantara, 2019:208). Objek penelitian atau sumber datanya adalah para guru PAUD peserta diklat berjenjang tingkat dasar bagi guru PAUD dalam jaringan. Waktu penelitian bulan Mei 2018 sampai dengan Desember 2018. Objek Penelitian adalah guru-guru PAUD yang berlokasi di 11 kecamatan, di Room
28 dengan jumlah peserta sebanyak 42 orang.

Jenis penelitian yang digunakan adalah penelitian deskriptif yaitu suatu penelitian yang dilakukan untuk memdeskripsikan secara terperinci tentang situasi dan keadaan dari suatu fenomena (Suradika, 2000: 13). Pada penelitian ini dilakukan wawancara dan dokumentasi untuk mengumpulkan data-data yang valid sehingga akan diketahui bagaimana efektifitas penyelenggaraan program diklat berjenjang tingkat dasar bagi guru PAUD dalam jaringan.

Untuk memperoleh data dan analisis maka teknik pengumpulan data dilakukan dengan tiga teknik pengumpulan data, yaitu: (a) observasi, (b) wawancara dan (c) dokumentasi.

\section{HASIL DAN PEMBAHASAN}

Program diklat berjenjang dalam jaringan bagi guru PAUD memiliki tiga jenis diklat yaitu:

a) Diklat Dasar dengan beban sebanyak48 pelajaran@45 menit dan 210 jam pelajaran tugas mandiri yang ditujukan untuk mempersiapkan pendidik dengan kompetensi minimal sebagai guru pendamping muda.

b) Diklat Lanjutan dengan beban waktu sebanyak 64 jam pelajaran (a)45 menit dan 210 jam pelajaran tugas mandiri yang ditujukan untuk mempersiapkan pendidik dengan kompetensi minimal sebagai guru pendamping.

c) Diklat mahir ditujukan dengan beban waktu sebanyak 80 jam pelajaran@45 menit tatap muka dan 210 jam pelajaran tugas mandiri untuk mempersiapkan pendidik dengan kompetensi minimal sebagai guru PAUD.

Pada diklat berjenjang tingkat dasar dan lanjutan, tugas mandiri yang berbobot 210 jam pelajaran terbagi menjadi: 
a) Tugas mandiri wajib

b) Tugas mandiri pilihan

c) Kunjungan belajar local

d) Kegiatan di gugus PAUD

e) Penyusunan laporan pelaksanaan tugas mandiri.

Komponen yang terlibat dalam pelaksanaan Diklat ini yaitu:
a) Penyelenggara
b) Narasumber
c) Pengampu
d) Mentor
e) Admin
f) Peserta Diklat

Bahan Ajar yang disampaikan memiliki tujuan bagi peningkatan kompetensi guru PAUD, dengan harapan dapat diimplementasikan di masingmasing lembaga setelah kegiatan diklat ini berakhir. Di dalam pelaksanaan diklat ini peserta wajib mengupload setiap materi yang didalamnya terdapat penugasanpenugasan wajib dikerjakan oleh peserta. Tugas dalam setiap materi dikerjakan dengan cara upload tugas, dan mentor akan memberikan penilaian terhadap tugas yang telah dikerjakan. Peserta dapat melihat hasil penilaian dan peserta juga dapat memperbaiki jawaban yang dianggap salah. Perbaikan dapat dilakukan dengan melakukan pelaporan terlebih dahulu kepada mentor, dan mentor akan menghapus jawaban peserta yang salah.

Model pembelajaran yang dilaksanakan dalam program diklat berjenjang tingkat dasar adalah: 1) model pembelajaran jarak jauh melalui penggunaan berbagai media komunikasi, 2) proses pembelajaran dilakukan secara elektronik (e-leraning) dengan memanfaatkan paket informasi berbasis teknologi informasi dan komunikasi untuk kepentingan pembelajaran yang diakses oleh peserta diklat kapan saja dan di mana saja, 3) bahan ajar dikemas dan dikembangkan berbasis teknologi informasi dan komunikasi dan digunakan sebagai bahan pembelajaran, 4) pembelajaran jarak jauh ini bersifat terbuka, belajar mandiri, belajar tuntas, menggunakan teknologi dan komunikasi.

Metode yang digunakan dalam diklat berjenjang tingkat dasar dalam jaringan ini merupakan metode kombinasi, artinya bahwa metode pembelajaran dilakukan melalui daring (dalam jaringan) dan luring (luar jaringan). Metode ini sangat layak untuk digunakan di dalam kegiatan diklat berjenjang tingkat dasar dalam jaringan ini, akan tetapi jika kegiatan diklat ini menggunakan metode daring murni akan lebih efektif lagi. Penggunaan metode yang baik akan dapat meningkatkan pemerataan akses terhadap pembelajaran bermutu.

Media memanfaatkan dalam pengerjaan tugas modul dan juga tugas mandiri, karena laporan yang diserahkan kepada panitia penyelenggara dalam bentuk hardcopy dan softcopy. Media yang dimaksud adalah:
a) Media Komputer yang menggunakan jaringan Internet,
b) Media Handphone.

Di dalam pelaksnaan Diklat Berjenjang Tingkat Dasar ini, ada beberapa peserta yang memang masih belum lancar dalam pengopersaian media computer/laptop sehingga di dalam pengerjaan tugas banyak yang memang harus dibantu, dalam hal ini biasanya yang membantu adalah teman maupun keluarga.

Waktu sangat berhubungan dengan jadwal kegiatan diklat berjenjang tingkat dasar dalam jaringan. Jadwal kegiatan disusun dengan menginformasikan tentang alokasi waktu, jenis kegiatan, materi yang disampaikan sehingga kegiatan yang akan dilaksanakan bisa terkoordinir dengan baik. Kondisi di lapangan pada proses penyelenggaraan diklat berjenjang tingkat dasar dalam jaringan ternyata tidak sesuai dengan jadwal yang telah ditetapkan.

Untuk Bahan ajar atau materi yang disampaikan ada 9 materi pembelajaran yang akan diterima oleh peserta. Berikut 
materi dan tugas yang akan diberikan kepada peserta diklat:

\begin{tabular}{|c|c|c|}
\hline No & Materi & $\begin{array}{l}\text { Jumlah } \\
\text { Tugas }\end{array}$ \\
\hline 1. & $\begin{array}{ll}\text { Konsep } & \text { Dasar } \\
\text { PAUD } & \end{array}$ & 2 tugas \\
\hline 2. & $\begin{array}{l}\text { Perkembangan } \\
\text { Anak Usia Dini }\end{array}$ & 3 tugas \\
\hline 3. & $\begin{array}{l}\text { Pengenalan } \\
\text { Anak } \\
\text { Berkebutuhan } \\
\text { Khusus }\end{array}$ & 2 tugas \\
\hline 4. & $\begin{array}{l}\text { Cara Belajar } \\
\text { Anak Usia Dini }\end{array}$ & 5 tugas \\
\hline 5. & $\begin{array}{l}\text { Kesehatan, } \\
\text { Gizi dan } \\
\text { Perawatan }\end{array}$ & 5 tugas \\
\hline 6. & $\begin{array}{l}\text { Perencanaan } \\
\text { Pembelajaran }\end{array}$ & 2 tugas \\
\hline 7. & $\begin{array}{l}\text { Penilaian } \\
\text { Pembelajaran } \\
\text { Anak }\end{array}$ & 2 tugas \\
\hline 8. & $\begin{array}{ll}\text { Etika } & \& \\
\text { Karakter } & \\
\text { Pendidik } & \\
\text { PAUD } & \end{array}$ & 2 tugas \\
\hline 9. & $\begin{array}{l}\text { Komunikasi } \\
\text { dan } \\
\text { Pengasuhan }\end{array}$ & 3 tugas \\
\hline
\end{tabular}

Model pembelajaran diklat berjenjang tingkat dasar dalam jaringan adalah model pembelajaran jarak jauh dengan pemanfaatan aplikasi berbasis web. Model pembelajaran jarak jauh dalam jaringan (online) sangat efektif untuk dilakukan oleh peserta yang memiliki keterbatasan jarak dan waktu, karena kegiatan ini memang dapat dilakukan di mana saja termasuk di rumah. Model ini memungkinkan peserta untuk menambah pengetahuan tentang teknologi informasi dan komunikasi, karena banyak sekali dari peserta yang pada awalnya mengalami kesulitan tentang penggunaan aplikasi.
Setahap demi setahap proses yang mereka lakukan dapat terselesaikan. Dari mulai registrasi untuk mendapatkan nomor registrasi, verifikasi data untuk mendapatkan username dan password, kegiatan pre-test, unduh materi, video conference, forum diskusi, upload tugas, post-test dilakukan secara online.

\section{KESIMPULAN}

Berdasarkan hasil penelitian, maka penulis dapat menarik kesimpulan bahwa pelaksanaan diklat berjenjang tingkat dasar bagi guru PAUD dalam jaringan belum efektif disebabkan oleh pemanfaatan waktu yang kurang efektif, media yang digunakan masih belum sempurna, Hal ini dapat digambarkan sebagai berikut:

\section{Pencapaian Tujuan}

Dalam proses pelaksanaan diklat peneliti melihat bahwa sasaran/tujuan dalam kegiatan ini adalah meningkatkan kompetensi guru, ketrampilan dan juga profesionalisme guru PAUD. Tetapi di dalam kenyataannya sasaran/tujuan itu tidak sepenuhnya berjalan dengan efektif karena masih ada beberapa peserta yang belum puas khususnya pserta yang senior yang merasa bahwa kegiatan diklat ini kurang cocok karena pemahaman teknologi inforamasi dan komunikasi yang kurang, sehingga diklat ini sangat cocok bagi para peserta muda karena akan lebih dapat menyerap ilmu dengan cepat dan memanfaatkan teknologi secara tepat.

\section{Proses Sosialisasi}

Dalam mewujudkan efektifitas pelaksanaan program diklat ini, sebaiknya digunakan proses sosialisasi sebagaimana dimaksud dilakukan oleh lembaga dengan tujuan untuk menyampaikan tujuan, isi serta manfaat dari kegiatan diklat dalam hal ini PP PAUD dan Dikmas di embaga masing-masing. Proses sosialisasi juga dilakukan untuk memberi pemahaman kepada semua pihak yang terlibat agar mereka tahu tujuan dan sasaran suatu 
program, sehingga tidak ada ketimpangan dalam pelaksanaannya.

Proses yang tidak kalah pentingnya adalah proses adaptasi atau penyesuian diri yang dilakukan untuk menyelaraskan suatu individu terhadap perubahan-perubahan yang terjadi dilingkungannya. Adaptasi ini menyangkut hal pengadaan tenaga kerja di mana dalam pelaksanaan kegiatan diklat ini para pelaksana dan pengelola dipilih berdasarkan pengalaman kerja dalam managani diklat, sedangkan pengajar dipilih berdasarkan keterampilan mereka dalam mengikuti kegiatan TOT. Dalam hal kuantitas jumlah pengajar sudah efektif, dalam hal kualitas para pengajar berkompeten dalam pengetahuan.

\section{SARAN}

Proses dari pelaksanaan diklat ini tentunya masih memiliki hambatanhambatan dan kekurangan yang perlu diperbaiki. Masukan serta kritik yang dapat disampaikan oleh peneliti mengenai pelaksanaan diklat ini, antara lain:

1) Perlu adanya perbaikan system dalam program diklat berjenjang tingkat dasar bagi guru PAUD dalam jaringan ini, agar peserta dapat melaksanakan kegiatan dengan lancar.

2) Jadwal pelaksanaan dilakukana sesuai dengan jadwal yang telah ditetapkan sehingga seluruh rangkaian pelaksanaan dapat lebih teratur.

3) Peserta diharapkan tidak terlambat dalam pengumpulan tugas sehingga tidak menghambat tugas mentor dalam memberikan penilaian.

4) Konsistensi terhadap standar penilaian lebih jelas, agar peserta dapat memahami bahwa yang dinyatakan lulus adalah peserta yang telah memenuhi standar penilaian ketuntasan.

\section{REFERENSI}

Arsyad, Azhar (2013). Media Pembelajaran. 2013. Jakarta: Raja Grafindo Persada

Bangun, Wilson (2008). Manajemen Sumber Daya Manusia. Jakarta: Erlangga

D. Dwiyogo Wasis (2018). Pembelajaran Berbasis Blended Learning. Depok: Raja Grafindo Persada

Fuad, H. Ihsan (2011). Dasar-Dasar Kependidikan. Jakarta: Rineka Cipta

Gomes, Cordose Fanstino (2003). Manajemen Sumber Daya Manusia. Yogyakarta: CV. Andi Offset

Hasibuan, S.P Melayu (2006). Manajemen Sumber Daya Manusia. Jakarta: PT. Bumi Aksara

https//zuhriindonesia.blogspot.com/2017/ 05/moda-pkb-2017-tatap mukadaring murni-daring kombinasi

Iswan, Herwina Bahar, Agus Suradika, Ahmad Susanto, Farihen Misriandi, Zainudin Hasan, "The Effect of Classroom Management Implementation on Student's Achievement." Universal Journal of Education Researc, Vol. 8, No. 11C, pp. 136-148, 2020. DOI: 10.13189/ujer.2020.082316

J. Drew Clifford, L. Hardman Michael dan L. Hosp John. Penelitian Pendidikan Merancang dan Melaksanakan Penelitian Pada Bidang Pendidikan. Jakarta: Indeks

M. Hosnan (2016). Etika Profesi Pendidikan. Bogor: Ghalia Indonesia

Makmur (2011). Efektifitas Kebijakan Kelembagaan Pengawasan. Bandung: Refika Aditama

Mangkunegara, Prabu Anwar A.A (2007). Manajemen Sumber Daya MAnusia Perusahaan. (Bandung: Remaja Rosdakarya 
Miarso, Yusufhadi (2004). Menyemai Benih Teknologi Pendidikan. Jakarta: Prenadamedia

Munir (2009). Pembelajaran Jarak Jauh Berbasis Teknologi Informasi dan Komunikasi. Bandung: Alfabeta

Notoatmodjo (2003), Soekidjo. Pengembangan Sumber Daya Manusia. Jakarta: Rineka.

Pusat Pengembangan Pendidikan Anak Usia dini dan Pendidikan Masyarakat (PP PAUD dan DIKMAS) (2018). Panduan Penyelenggaraan Diklat Berjenjang Tingkat Dasar Bagi Guru PAUD Dalam Jaringan. Jawa Barat.

Putra, Nusa dan Dwilestari Ninin (2012). Penelitian Kualitatif PAUD. Jakarta: Raja Grafindo Persada

Rahman, Misran, Jurnal "Pengembangan Model On The Job Tarining Berbasis Andargogi untuk Peningkatan Kompetensi Pendidikan Anak usia Dini Non Formal", (Jakarta: Kementrian Pendidikan Nasional Direktorat Jenderal Pendidikan Anak Usia Dini, Non formal, dan Informal Bekerjasama dengan Fakultas Ilmu Pendidikan Unuversitas Negeri Jakarta: 2011)

Rivai, Zaenal Veithzal dkk (2014). Manajemen Sumber Daya Manusia Untuk Perusahaan. Jakarta: PT. Raja Grafindo Persada

Riza, Eva, Jurnal “ Efektifitas Diklat Berjenjang Tingkat Dasar Pendidik Dan Tenaga Kependidikan PAUD ”, (Jakarta: Universitas Negeri Jakarta:2014)

Rozalena, Agustina dan Dewi Komala Sri (2017). Manajemen Pendidikan dan Pelatihan bagi Karyawan. (Jakarta: Raih Asa Sukses
S. P Hasibuan Malayu (2010). Manajemen Sumber Daya Manusia. Jakarta: Bumi Aksara

S. Sadiman Arief, Rahardjo, Haryono Anung, Rahardjito (2008). Media Pendidikan. Jakarta: Raja Grafindo Persada

Sastrohadiwiryo, Siswanto (2003). Manajeman Tenaga Kerja Indonesia. Jakarta: Bumi Aksara

Sedarmaryanti (2014). Manajemen Sumber Daya Manusia, Reformasi Birokrasi dan Manajemen Pegawai Negeri Sipil. Bandung: PT. Refika Aditama

Sugiyono (2010). Metodologi Penelitian Pendidikan. Bandung: Alfabeta

Suradika, Agus. (2000). Metode Penelitian Sosial. Jakarta: UMJ Press.

Suradika, Agus dan Wicaksono, Dirgantara. (2019). Metodelogi Penelitian. Jakarta: UM Jakarta Press

Susanto, Ahmad (2016). Manajemen Peningkatan Kinerja Guru. Jakarta: Prenadamedia

Suwanto (2013). Manajemen SDM dalam Organisasi Publik dan Bisnis. Bandung: Alfabeta

Teguh, Sulistiyani Ambar, Rosidah (2009). Manajemen Sumber Daya Manusi. Yogyakarta: Graha Ilmu

Tika, Moh. Pabundu (2010). Budaya Organisasi dan Peningkatan Kinerja perusahaan. Jakarta: Bumi Aksara

Umar, Husein (2011). Metode Penelitian Untuk Skripsi dan Tesis Bisnis. Jakarta: Rajawali press.

Uno, Hamzah B (2008). Model Pembelajaran. Jakarta: Bumi Aksara

Wilson, Bangun (2012). Manajemen Sumber Daya Manusia. Bandung: Erlangga 
Winata, Widia (2017). Internasional Jornal Of Multidisciplinary Research And Development. Jakarta: Universitas Muhammadiyah Jakarta

Yaong, Tung Khoe (2017). Desain Instruksional.. Yogyakarta: ANDI

Yusuf, Taybnapis Farida (2000). Evaluasi Program. Jakarta: Rineka Cipta

Mahsun, Muhamad (2006). Pengukuran Kinerja Sektor Publik. Yogyakarta 